\title{
Effects of Nerve Growth Factor- $\beta$ From Bull Seminal Plasma on Steroidogenesis and Angiogenic Markers of the Bovine Pre-ovulatory Follicle Wall Cell Culture
}

\author{
Jamie L. Stewart ${ }^{1,2,3}$, Liying Gao ${ }^{2}$, Jodi A. Flaws ${ }^{2}$, Vitor R. G. Mercadante ${ }^{4}$, \\ Nicholas W. Dias ${ }^{4}$, Igor F. Canisso ${ }^{1,2}$ and Fabio S. Lima ${ }^{5 *}$ \\ ${ }^{1}$ Department of Large Animal Clinical Sciences, Virginia-Maryland College of Veterinary Medicine, Virginia Polytechnic \\ Institute and State University, Blacksburg, VA, United States, ${ }^{2}$ Department of Comparative Biosciences, College of Veterinary \\ Medicine, University of Illinois, Urbana, IL, United States, ${ }^{3}$ Department of Veterinary Clinical Medicine, College of Veterinary \\ Medicine, University of Illinois, Urbana, IL, United States, ${ }^{4}$ Department of Animal and Poultry Sciences, Virginia Polytechnic \\ Institute and State University, Blacksburg, VA, United States, ${ }^{5}$ Department of Population Health and Reproduction, School of \\ Veterinary Medicine, University of California, Davis, Davis, CA, United States
}

\section{OPEN ACCESS}

Edited by:

Massimo Zerani,

University of Perugia, Italy

Reviewed by:

Mauricio Silva,

Temuco Catholic University, Chile

Marcelo H. Ratto,

Austral University of Chile, Chile

*Correspondence:

Fabio S. Lima

falima@ucdavis.edu

Specialty section:

This article was submitted to Animal Reproduction -

Theriogenology,

a section of the journal

Frontiers in Veterinary Science

Received: 30 September 2021 Accepted: 20 December 2021

Published: 17 January 2022

Citation:

Stewart JL, Gao L, Flaws JA,

Mercadante VRG, Dias NW, Canisso IF and Lima FS (2022) Effects of Nerve Growth Factor- $\beta$ From Bull Seminal Plasma on Steroidogenesis and Angiogenic Markers of the Bovine Pre-ovulatory Follicle Wall Cell Culture.

Front. Vet. Sci. 8:786480.

doi: 10.3389/fvets.2021.786480
Nerve growth factor- $\beta$ (NGF) is critical for ovulation in the mammalian ovary and is luteotrophic when administered systemically to camelids and cattle. This study aimed to assess the direct effects of purified bovine NGF on steroidogenesis and angiogenic markers in the bovine pre-ovulatory follicle. Holstein heifers $(n=2)$ were synchronized with a standard protocol, and heifers with a preovulatory follicle $(\geq 12 \mathrm{~mm}$ ) had the ovary containing the dominant follicle removed via colpotomy. Pre-ovulatory follicles were dissected into 24 pieces containing theca and granulosa cells that were randomly allocated into culture media supplemented with either purified bovine NGF $(100 \mathrm{ng} / \mathrm{mL})$ or untreated (control) for $72 \mathrm{~h}$. The supernatant media was harvested for quantification of progesterone, testosterone, and estradiol concentrations, whereas explants were subjected to mRNA analyses to assess expression of steroidogenic and angiogenic markers. Treatment of follicle wall pieces with NGF upregulated gene expression of steroidogenic enzyme HDS17B $(P=0.04)$ and increased testosterone production $(P$ $<0.01)$. However, NGF treatment did not alter production of progesterone $(P=0.81)$ or estradiol $(P=0.14)$. Consistently, gene expression of steroidogenic enzymes responsible for producing these hormones (STAR, CYP11A1, HSD3B, CYP17A1, CYP19A1) were unaffected by NGF treatment $(P \geq 0.31)$. Treatment with NGF downregulated gene expression of the angiogenic enzyme FGF2 $(P=0.02)$ but did not alter $P G E S(P=0.63)$, VEGFA $(P=0.44)$, and ESR1 $(P=0.77)$. Collectively, these results demonstrate that NGF from seminal plasma may interact directly on the theca and granulosa cells of the bovine pre-ovulatory follicle to stimulate testosterone production, which may be secondary to theca cell proliferation. Additionally, decreased FGF2 expression in NGF-treated follicle wall cells suggests hastened onset of follicle wall cellular remodeling that occurs during early luteal development.

Keywords: angiogenesis, NGF, granulosa cells, theca cells, ruminants 


\section{INTRODUCTION}

Nerve growth factor- $\beta$ (NGF) is a member of the neurotrophin family that has a critical role in mammalian follicle development and ovulation $(1,2)$. Expression of NGF has been localized to ovarian granulosa cells prior to the formation of the first primordial follicles in neonatal mice (2). Though present during late fetal development, expression of NGF and its receptor, TrkA, in the ovary decreases postnatally between 24 and $48 \mathrm{~h}$ after birth and remains low until puberty in rats (1). At the time of the first pre-ovulatory luteinizing hormone (LH) surge, transient activation of NGF/TrkA occurs, and contributes to follicular cytodifferentiation preceding the first ovulation (1). In bovine theca cells, NGF induced prostaglandin $E_{2}$ (PGE) synthesis (3), which facilitates follicular rupture at ovulation (4). The presence of both LH and follicle-stimulating hormone (FSH) in vitro were necessary to stimulate NGF secretion from medium to large follicles in ewes, suggesting a synergistic role with gonadotropins during the pre-ovulatory cascade (5).

Though the ability of the ovary to produce NGF in spontaneously ovulating species is well-documented, few studies have evaluated whether the introduction of NGF from seminal plasma at time of breeding may have a role within the bovine hypothalamic-pituitary-ovarian axis $(6,7)$. In camelids, intrauterine absorption of seminal plasma NGF into systemic circulation occurs within $15 \mathrm{~min}$ of copulation, after which it stimulates the preovulatory LH peak from the anterior pituitary gland and exerts a dose-dependent luteotropic effect on the developing corpus luteum (CL) (8). Studies have shown that NGF retains its luteotropic properties when administered systemically to cattle (7). While the luteotropic effect in camelids is attributed to prolonged $\mathrm{LH}$ secretion from the anterior pituitary, in cattle, there is evidence that NGF may act directly on the ovary (3).

Similar to camelids, bull seminal plasma contains NGF, which is concentrated into the sperm-rich fraction of the ejaculate, facilitating its transit into the cow reproductive tract (9). The bovine uterus maintains a local countercurrent exchange between the uterine venous drainage and the ovarian artery that allows for direct transport of prostaglandin $F_{2 \alpha}$ $\left(\mathrm{PGF}_{2 \alpha}\right)$ from the uterus to the ovary during luteolysis $(10,11)$. This anatomical mechanism could also provide a potential route for NGF to travel to and interact directly with the ovary (12). A previous study demonstrated that treating bovine theca cells with recombinant NGF in vitro resulted in increased androstenedione and progesterone release, PGE production, and theca cell proliferation when compared to hCG-treated controls (3). However, the signaling cascade within the ovary involves a complex interaction between the theca and granulosa cells, which has yet to be elucidated. This study aimed to assess the direct effects of NGF, purified from bull seminal plasma, on steroidogenesis and angiogenic markers in theca and granulosa cells of the bovine pre-ovulatory follicle. We hypothesized that NGF administration would stimulate steroidogenesis and angiogenic markers in thecal and granulosa cells from the bovine preovulatory follicle.

\section{MATERIALS AND METHODS}

\section{Animal Care and Use}

The present study was conducted in 2018 at the College of Veterinary Medicine, University of Illinois Urbana-Champaign. The Institutional Animal Care approved all the animal procedures and Use Committees of the University of Illinois at Urbana-Champaign, USA (Protocol \#18223).

\section{Heifer Synchronization and Ovariectomy}

A cohort of three cyclic Holstein heifers (presence of corpus luteum $>16 \mathrm{~mm}$ and pre-ovualtory follicle $>12 \mathrm{~mm}$ ) of $\sim 2$ years of age had their estrous cycles synchronized. The heifers received an intravaginal progesterone-releasing device $(1.38 \mathrm{~g}$ progesterone; Eazi-Breed CIDR, Zoetis, Parsippany-Troy Hills, NJ, USA) and an injection of GnRH agonist (100 $\mu$ g Factrel ${ }^{\circledR}$, Zoetis, Parsippany-Troy Hills, NJ, USA) intramuscularly (day -8 ). The intravaginal device was removed 5 days later (day -3 ), and heifers were given $\mathrm{PGF}_{2 \alpha}$ analog (25 $\mathrm{mg}$ dinoprost tromethamine, Lutalyse, Zoetis, Parsippany-Troy Hills, NJ, USA) intramuscularly at the time of the intravaginal device removal and again $24 \mathrm{~h}$ later (day -2 ). Heifers were examined daily by transrectal ultrasonography to assess response to the synchronization program. At day 0 ( $48 \mathrm{~h}$ after the second $\mathrm{PGF}_{2 \alpha}$ injection), heifers that had undergone complete luteolysis and dominant follicle selection, as determined by the absence of a $\mathrm{CL}$ and the presence of a $>12 \mathrm{~mm}$ follicle, were subjected to ovariectomy. Ovariectomy was performed via colpotomy in the standing position under caudal epidural anesthesia with $5 \mathrm{~mL}$ of $2 \%\left(\right.$ w/v) lidocaine $\mathrm{HCl}$ (VetOne ${ }^{\circledR}$, Boise, Idaho, USA). Only the ovary containing a dominant, pre-ovulatory follicle was removed. One heifer was excluded from the study after being unable to remove the ovary containing the dominant follicle. Heifers were treated pre-operatively with ceftiofur crystalline free acid $\left(6.6 \mathrm{mg} / \mathrm{kg}\right.$; Excede ${ }^{\circledR}$, Zoetis, Parsippany-Troy Hills, NJ, USA) injected subcutaneously in the base of the ear to prevent infection. Flunixin meglumine $\left(2.2 \mathrm{mg} / \mathrm{kg}\right.$; Norbrook ${ }^{\circledR}$ Inc., Overland Park, KS, USA) was administered intravenously daily for 2 days to control inflammation and pain. Ovaries were placed in ice-cold phosphate-buffered saline solution containing $2 \%$ antibiotic-antimycotic mixture $(25 \mu \mathrm{g} / \mathrm{mL}$ amphotericin $\mathrm{B}$, 10,000 units/mL penicillin, $10,000 \mu \mathrm{g} / \mathrm{mL}$ streptomycin; Gibco, Gaithersburg, MD, USA) for transport to the laboratory.

\section{Isolation of Follicular Wall Cells and Treatment Allocation}

The pre-ovulatory follicle was identified and dissected away from each ovary for use in the follicle wall cell culture system. Follicular fluid was aspirated to facilitate further dissection and frozen at $-80^{\circ} \mathrm{C}$. The follicles were dissected into quarters, and the theca interna with adherent granulosa cells was peeled from the theca externa and surrounding stromal wall cells. The remaining follicle wall preparations (theca interna and granulosa cells) were cut into 26 pieces (average weight: $5.3 \pm 0.7 \mathrm{mg}$ ), 24 of which were transferred to a costar 24-well-plate (1 piece/well; Cambridge, MA, USA) for follicle wall culture, as previously described $(13,14)$. The remainder of the follicle wall was 
TABLE 1 | List of genes and primers used for quantitative real-time PCR.

\begin{tabular}{|c|c|c|c|}
\hline Target genes and abbreviations & NCBI Sequence & Primer & Primer sequence \\
\hline Glyceraldehyde-3-phosphate dehydrogenase (GAPDH) & NM_001034034 & $\begin{array}{l}\text { Forward } \\
\text { Reverse }\end{array}$ & $\begin{array}{l}\text { 5'-GGCGCCAAGAGGGTCAT-3' } \\
\text { 5'-ACGCCCATCACAAACATGG-3 }\end{array}$ \\
\hline Ribosomal protein L 15 (RPL15) & AY786141 & $\begin{array}{l}\text { Forward } \\
\text { Reverse }\end{array}$ & $\begin{array}{l}\text { 5'-TGGAGAGTATTGCGCCTTCTC-3' } \\
\text { 5'-CACAAGTTCCACCACACTATTGG-3' }\end{array}$ \\
\hline Ribosomal protein L 19 (RPL19) & NM_001040515 & $\begin{array}{l}\text { Forward } \\
\text { Reverse }\end{array}$ & $\begin{array}{l}\text { 5'-CAGACGATACCTGAATCTAAGAAGA-3' } \\
\text { 5'-TGAGAATCCGCTTGTIITGAA-3' }\end{array}$ \\
\hline Follicular stimulating hormone receptor (FSHR) & NM_174061 & $\begin{array}{l}\text { Forward } \\
\text { Reverse }\end{array}$ & $\begin{array}{l}5^{\prime} \text {-CGACTCTGTCACTGCTCTAACGG-3' } \\
5^{\prime} \text {-CGTCAATTCCTTGGCATAGGTGG-3' }\end{array}$ \\
\hline Luteinizing hormone/ choriogonadotropin receptor (LHCGR) & NM_174381 & $\begin{array}{l}\text { Forward } \\
\text { Reverse }\end{array}$ & $\begin{array}{l}\text { 5'-CAGTCCCCCGCTTCTCAT-3' } \\
\text { 5'-GTAGAGCCCCATGCAGAAGTCT-3' }\end{array}$ \\
\hline Steroidogenic acute regulatory protein (STAR) & XR_083945 & $\begin{array}{l}\text { Forward } \\
\text { Reverse }\end{array}$ & $\begin{array}{l}\text { 5'-GGATTAACCAGGTTCGGCG-3' } \\
\text { 5'-CTCTCCTTCTTCCAGCCCTC-3' }\end{array}$ \\
\hline Cytochrome P450 family 11 subfamily A member 1 (CYP11A1) & NM_176644 & $\begin{array}{l}\text { Forward } \\
\text { Reverse }\end{array}$ & $\begin{array}{l}\text { 5'-GCCACATCGAGAACTTCCAGAAG-3' } \\
\text { 5'-CTGGTGTGGAACATCTTGTAGACG-3' }\end{array}$ \\
\hline Hydroxyl-delta-5-steroid dehydrogenase 3-beta (HSD3B) & NM_174343 & $\begin{array}{l}\text { Forward } \\
\text { Reverse }\end{array}$ & $\begin{array}{l}\text { 5' -TGTTGGTGGAGGAGAAGGATCTG-3' } \\
5^{\prime} \text {-TGGGTACCTITCACATTGACGTTC-3' }\end{array}$ \\
\hline Hydroxysteroid 17-beta dehydrogenase (HSD17B) & NM_001102365 & $\begin{array}{l}\text { Forward } \\
\text { Reverse }\end{array}$ & $\begin{array}{l}\text { 5' -TTGTGCGAGAGTCTGGCGATTCT-3' } \\
5^{\prime} \text {-AGGAATCGCTCGGTGGTGAAGTA-3' }\end{array}$ \\
\hline Cytochrome P450 family 17 subfamily A member 1 (CYP17A1) & NM_174304 & $\begin{array}{l}\text { Forward } \\
\text { Reverse }\end{array}$ & $\begin{array}{l}\text { 5'-TGTGGCCCCTACGCTGAT-3' } \\
\text { 5'-CGCCAATGCTGGAGTCAAT-3' }\end{array}$ \\
\hline Cytochrome P450 family 19 subfamily A member 1 (CYP19A1) & NM_174305 & $\begin{array}{l}\text { Forward } \\
\text { Reverse }\end{array}$ & $\begin{array}{l}5^{\prime} \text {-GTCCGAAGTTGTGCCTATTGCCAGC-3' } \\
5^{\prime} \text { - CCTCCAGCCTGTCCAGATGCTTGG-3' }\end{array}$ \\
\hline Estrogen receptor 1 (ESR1) & NM_001001443 & $\begin{array}{l}\text { Forward } \\
\text { Reverse }\end{array}$ & $\begin{array}{l}\text { 5'-AGGGAAGCTCCTATITGCTCC-3' } \\
\text { 5'-CGGTGGATGTGGTCCTTCTCT-3' }\end{array}$ \\
\hline Fibroblast growth factor 2 (FGF2) & NM_174056 & $\begin{array}{l}\text { Forward } \\
\text { Reverse }\end{array}$ & $\begin{array}{l}\text { 5'-GAACGGGGGCTTCTTCCT-3' } \\
\text { 5'-CCCAGTTCGTTCAGTGCC-3' }\end{array}$ \\
\hline Prostaglandin E synthase (PGES) & NM_174443 & $\begin{array}{l}\text { Forward } \\
\text { Reverse }\end{array}$ & $\begin{array}{l}\text { 5'-AGGACGCTCAGAGACATGGA-3' } \\
\text { 5'-TTCGGTCCGAGGAAAGAGTA-3' }\end{array}$ \\
\hline Vascular endothelial growth factor A isoform 121 (VEGFA121) & NM_174216 & $\begin{array}{l}\text { Forward } \\
\text { Reverse }\end{array}$ & $\begin{array}{l}\text { 5'- CCGTCCCATTGAGACCCTG-3' } \\
\text { 5'-CGGCTTGTCACAATाITCTTGTC-3' }\end{array}$ \\
\hline
\end{tabular}

flash-frozen in liquid nitrogen and maintained at $-80^{\circ} \mathrm{C}$ until mRNA extraction.

The dissected 24 follicle wall pieces containing theca and granulosa cells were randomly allocated to receive a culture medium that was either supplemented with purified bovine NGF (100 ng/mL, $n=2$ heifers; 6 follicle wall piece replicates from each) or left untreated (control, $n=2$ heifers; 6 follicle wall piece replicates from each). The single plate was incubated at $37^{\circ} \mathrm{C}$ in a humidified incubator gassed with $5 \% \mathrm{CO}_{2}: 95 \%$ air for $72 \mathrm{~h}$. The NGF was purified from bovine seminal plasma, as described previously (7). The follicle wall pieces were cultured in $0.5 \mathrm{~mL}$ of medium consisting of Eagle's MEM (Invitrogen, Carlsbad, CA, USA) supplemented with 1\% L-glutamine (Gibco, Gaithersburg, MD, USA), 1\% non-essential amino acids (SigmaAldrich, St. Louis, MO, USA), $1 \%$ penicillin-streptomycin (Sigma-Aldrich), $1 \%$ ITS (10 ng/ml insulin, $5.5 \mathrm{ng} / \mathrm{ml}$ transferrin, $5.5 \mathrm{ng} / \mathrm{ml}$ selenium, Sigma-Aldrich), $10 \%$ fetal bovine serum (FBS, Atlanta Biologicals, Lawrenceville, GA), $40 \mathrm{ng} / \mathrm{mL}$ cortisol (Sigma-Aldrich), $4 \mathrm{ng} / \mathrm{mL}$ human recombinant LH (Dr. A. F. Parlow, National Hormone and Peptide Program, Harbor- UCLA Medical Center, Torrance, CA, USA), and $4 \mathrm{ng} / \mathrm{mL}$ human recombinant FSH (Dr. A. F. Parlow, National Hormone and Peptide Program).

\section{Hormone Assays}

At each experimental time point during culture $(3,6,12$, $24,48$, and $72 \mathrm{~h})$, aliquots $(0.5 \mathrm{~mL})$ of culture medium were collected and preserved at $-20^{\circ} \mathrm{C}$ for subsequent steroid assays. A fresh $0.5 \mathrm{~mL}$ aliquot of media, containing NGF treatment or control, was added to each well at each time point except $72 \mathrm{~h}$ when the experiment was completed. Progesterone, testosterone, and estradiol-17 $\beta$ concentrations at each time point in the culture media were assessed using immunoassays (Immulite $2000 \mathrm{XPi}$ platform; Siemens Medical Solutions, Malvern, PA, USA, Inc.). Total hormone production for each well was calculated by multiplying the measured concentration by the volume of media $(0.5 \mathrm{~mL})$ and then dividing by follicle wall cells weight $(\mathrm{mg})$. Intraassay coefficient of variations were $4.0 \%$ (testosterone), $2.4 \%$ (progesterone), and 3.1\% (estradiol-17 $\beta$ ). Inter-assay coefficient of variations were $12 \%$ (testosterone), 19\% (progesterone), and $15 \%$ (estradiol-17 $\beta$ ). The progesterone assay had a detection range of $0.2-40 \mathrm{ng} / \mathrm{mL}$ and a sensitivity of $0.1 \mathrm{ng} / \mathrm{mL}$. The testosterone assay had a detection range of $20-1,600 \mathrm{ng} / \mathrm{mL}$ and a sensitivity of $15 \mathrm{ng} / \mathrm{dL}$. The estradiol-17 $\beta$ assay had a detection range of $20-2,000 \mathrm{pg} / \mathrm{mL}$ and a sensitivity of $15 \mathrm{pg} / \mathrm{mL}$. 


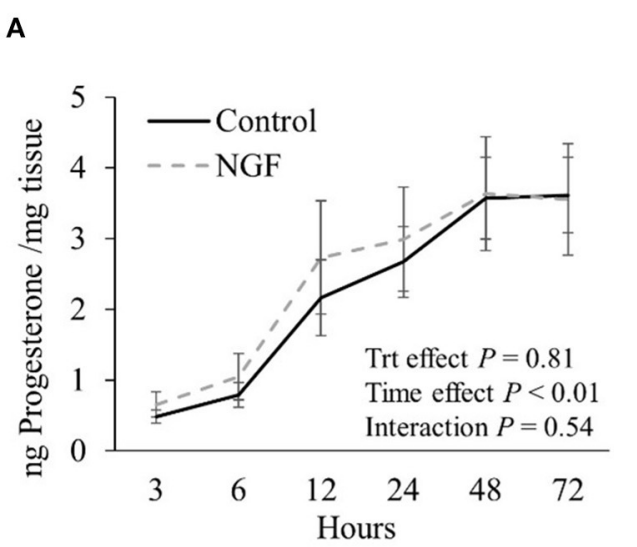

C

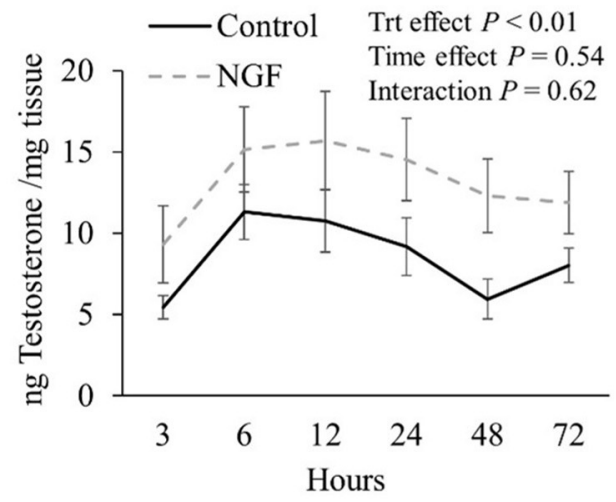

$\mathbf{E}$

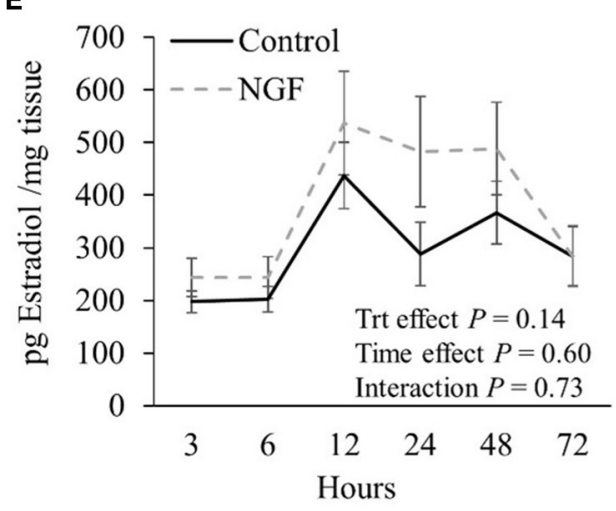

B

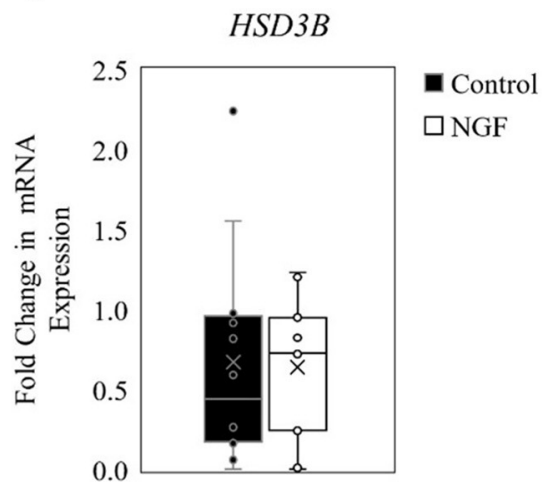

D

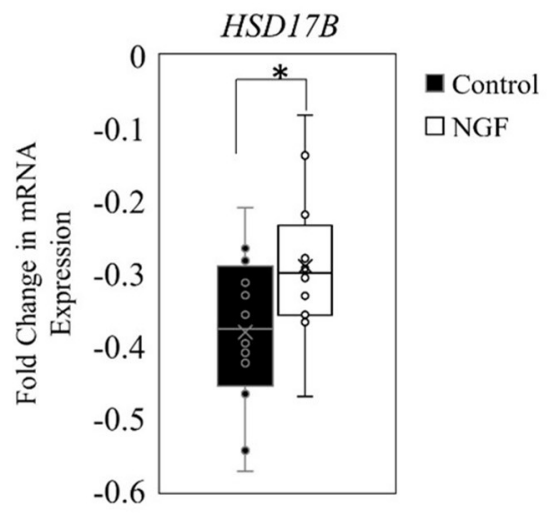

$\mathbf{F}$

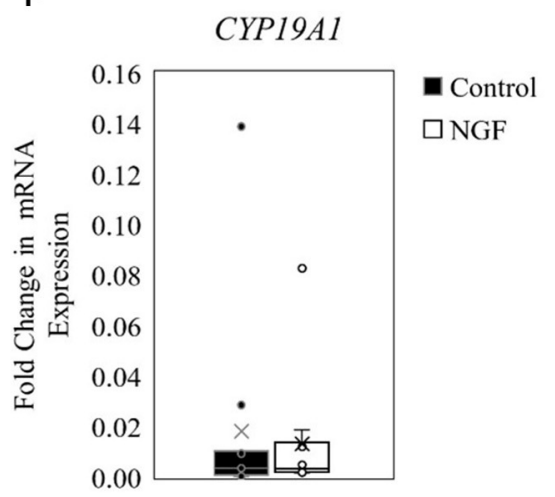

FIGURE 1 | Steroid hormone production (A,C,E) and steroidogenic enzyme gene expression (B,D,F) in follicle wall cells untreated (control) or treated with $100 \mathrm{ng} / \mathrm{mL}$ NGF for $72 \mathrm{~h}$. Hormones are presented as mean \pm SEM, whereas genes are presented as box-and-whisker plots. ${ }^{*} P \leq 0.05$.

\section{Quantitative Real-Time PCR Analyses}

At the completion of the $72-\mathrm{h}$ culture period, follicle wall pieces were weighed and flash-frozen and kept at $-80^{\circ} \mathrm{C}$ until RNA extraction. Follicular wall cells mRNA expression was determined for $\mathrm{LH}$ /choriogonadotropin receptor (LHCGR), FSH receptor (FSHR), PGE synthase (PGES), vascular endothelial growth factor A isoform 121 (VEGFA121), fibroblast growth factor 2 (FGF2), estrogen receptor 1 (ESR1), steroidogenic acute regulatory protein (STAR), cytochrome P450 family 11 subfamily A member 1 (CYP11A1), cytochrome P450 family 17 subfamily A member 1 (CYP17A1), cytochrome P450 family 19 subfamily A member 1 (CYP19A1), hydroxyl-delta-5steroid dehydrogenase 3-beta (HSD3B), and hydroxysteroid 17beta dehydrogenase $(H S D 17 B)$. Primers were designed for the constitutively expressed mRNAs, glyceraldehyde-3-phosphate dehydrogenase (GAPDH), ribosomal protein L 15 (RPL15), and 
TABLE 2 | Fold change in mRNA expression of gonadotropin receptors, angiogenic enzymes, and steroidogenic enzymes in bovine follicle wall cells preparations treated with $100 \mathrm{ng} / \mathrm{mL}$ NGF vs. untreated (Control) for $72 \mathrm{~h}$.

\begin{tabular}{|c|c|c|c|}
\hline Gene names and abbreviations & Control & NGF & $P$-value \\
\hline Steroidogenic acute regulatory protein (STAR) & $0.17 \pm 0.02$ & $0.29 \pm 0.1$ & 0.34 \\
\hline Cytochrome P450 family 11 subfamily A member 1 (CYP11A1) & $17.81 \pm 9.2$ & $8.67 \pm 5.0$ & 0.40 \\
\hline Cytochrome P450 family 17 subfamily A member 1 (CYP17A1) & $0.01 \pm 0.00$ & $0.01 \pm 0.00$ & 0.31 \\
\hline Luteinizing hormone/ choriogonadotropin receptor (LHCGR) & $0.07 \pm 0.01$ & $0.09 \pm 0.03$ & 0.41 \\
\hline Follicular stimulating hormone receptor (FSHR) & Undetected & Undetected & N/A \\
\hline Estrogen receptor alpha (ESR1) & $0.04 \pm 0.01$ & $0.05 \pm 0.02$ & 0.77 \\
\hline
\end{tabular}

Data is presented as mean \pm SEM.

ribosomal protein L 19 (RPL19), with the expression value of each gene normalized to the mean values of these genes (Table 1). Relative expression values were obtained by determining the PCR amplification efficiency $(\mathrm{E}=2)$ to the power of the delta-delta threshold cycle $(\Delta \Delta \mathrm{Ct})$ obtained from the $\Delta \mathrm{Ct}$ least square mean differences of pairwise comparisons between initial and cultured follicle wall cells (15).

Follicle wall cell lysis and RNA extraction were conducted according to the manufacturer's recommendations (PureLink RNA Mini Kit, Invitrogen, Carlsbad, CA, USA). Isolated RNA was evaluated for concentration and purity using a NanoDrop One Spectrophotometer (Thermo Fisher Scientific, Waltham, MA, USA). A maximum of $2 \mu \mathrm{g}$ of mRNA was used to synthesize complementary DNA using a commercial kit (High-capacity cDNA Reverse Transcription Kit, Applied Biosystems, Foster City, CA, USA) supplemented with RNase inhibitor (RNase Inhibitor, human placenta, New England BioLabs, Ipswich, MA, USA). Complementary DNA was used for quantitative real-time reverse transcription PCR using a 7500 Real-Time PCR Detection System (Applied Biosciences) with PowerUp ${ }^{\mathrm{TM}} \mathrm{SYBR}^{\mathrm{TM}}$ Green Master Mix (2X; Applied Biosciences). All assays were carried out in triplicate for each target mRNA. The amplification conditions were as follows: $50^{\circ} \mathrm{C}$ for $2 \mathrm{~min}, 95^{\circ} \mathrm{C}$ for $2 \mathrm{~min}$, and 40 cycles at $95^{\circ} \mathrm{C}$ for $15 \mathrm{~s}$ and $60^{\circ} \mathrm{C}$ for $60 \mathrm{~s}$.

\section{Statistical Analyses}

Data are presented as percentage mean \pm SEM. All statistical analyses were performed using R Version 3.4.3 (https://www. r-project.org/). Normality was confirmed using a Shapiro-Wilk test of the residuals. Non-normal data were transformed using Tukey's Ladder of Powers. If transformation did not result in a normalized population, a Kruskal-Wallis rank-sum test was performed. Analysis of variance was applied to parametric data using a general linear mixed model with repeated measures applied for hormone data. Heifer ID was included as a random variable with each follicle wall piece serving as a replicate for each heifer. Significance was declared at $P \leq 0.05$.

\section{RESULTS}

Progesterone production from follicular wall cells (Figure 1A) changed over time in the culture system $(P<0.01)$ but was not altered by NGF treatment $(P=0.81)$ or treatment by time

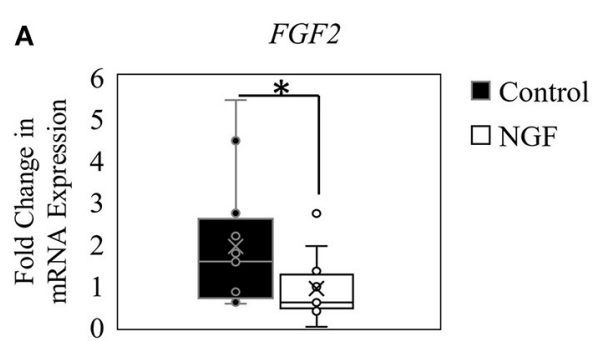

B $\quad V E G F A$

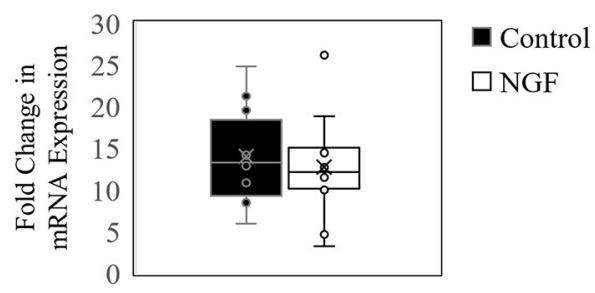

C $P G E S$

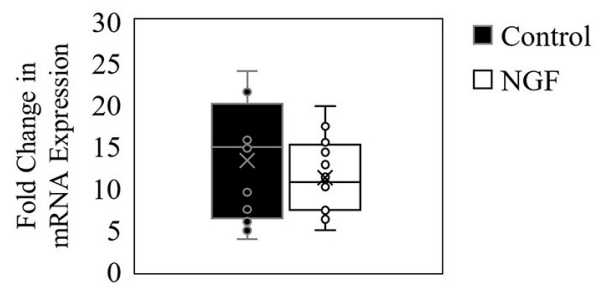

FIGURE 2 | Box-and-whisker plots demonstrating gene expression of angiogenic enzymes FGF2 (A), VEGFA (B), and PGES (C) in follicle wall cells untreated (control) or treated with $100 \mathrm{ng} / \mathrm{mL}$ NGF for $72 \mathrm{~h}$. ${ }^{*} P \leq 0.05$.

interactions $(P=0.54)$. Consistently, there were no changes in gene expression of steroidogenic enzymes responsible for the conversion of cholesterol to pregnenolone (STAR, CYP11A1; $P \geq 0.34$; Table 2 ) or pregnenolone to progesterone (HSD3B; $P=0.60$, Figure 1B) after treatment with NGF for $72 \mathrm{~h}$. Testosterone production in NGF-treated follicular wall cells (Figure 1C) was higher than in untreated controls $(P<0.01)$, but not affected by time $(P=0.54)$ or treatment by time interactions $(P=0.62)$. While there was no change in follicular CYP17A1 expression ( $P=0.31$; Table 2$)$, whose enzyme converts 
progesterone to androstenedione, NGF treatment upregulated follicular $H S D 17 B$ expression $(P=0.04$; Figure 1D), whose enzyme converts androstenedione to testosterone in the theca cells (13). Follicular estradiol production (Figure 1E) was unaffected by NGF treatment $(P=0.14)$, time $(P=0.60)$, or treatment by time interactions $(P=0.73)$. Consistently, follicular CYP19A1 expression was also unaffected by NGF treatment $(P=$ 0.53; Figure 1F).

Follicular expression of LHCGR was unaltered by treatment after $72 \mathrm{~h}$ culture $(P=0.41)$, whereas FSHR was undetectable by the assay (Table 2). We also found no increase in the expression of ESR1 following the 72-h culture period in either treatment group $(P=0.77$; Table 2$)$.

The results herein also demonstrated that NGF treatment down-regulated expression of FGF2 ( $P=0.02$; Figure 2A), but did not alter VEGFA $121(P=0.44$; Figure $2 \mathrm{~B})$ or $P G E S(P=0.63$;

Figure 2C) expression in bovine follicle wall cells.

\section{DISCUSSION}

The current study evaluated the direct effects of NGF, purified from bull seminal plasma, on bovine pre-ovulatory follicle wall cells. In a previous study, androstenedione and progesterone production was increased in isolated bovine theca cells treated with recombinant NGF (3). Androstenedione is converted to testosterone in the theca cells by the enzyme hydroxysteroid 17-beta dehydrogenase (HSD17B) (13), both of which were increased in the current study. Testosterone produced by theca cells is typically converted to estradiol in the granulosa cell via the aromatase enzyme (13). Despite the increased production of its testosterone precursor, estradiol concentrations, and aromatase enzyme gene expression (CYP19A1) were unaffected by NGF treatment. Previously, ESR1 expression was observed in the theca interna cells of growing pre-ovulatory follicles in the bovine ovary and thought to provide a local feedback loop, whereby estradiol produced by granulosa cells could be used to further stimulate theca cell androgen production (16). In that study, highest expression of ESR1 was detected during follicular growth and in the early luteal phase (day 1 through 4 of the estrous cycle) (16). The current study did not find an effect of NGF treatment of ESR1 expression in bovine follicular wall cells, further suggesting that this feedback loop is not the potential signaling mechanism for NGF-induced androgen production. However, NGF stimulated proliferation of theca cells from bovine pre-ovulatory follicles (3). Therefore, the increase in testosterone production observed herein could be due to an increase in theca cell number, since estradiol production by the granulosa cells was unaffected.

Treatment of follicle wall cells with NGF did not alter the expression of other steroidogenic enzymes or progesterone production, which serves as a precursor for androstenedione production in the preovulatory follicle (13). This is contradictory to the previous observation of increased theca cell progesterone production in response to NGF treatment (3). One difference between studies is that our culture media contained gonadotropins (LH/FSH) in both control and NGF wells, attempting to emulate the pre-ovulatory cascade, whereas the previous study treated only the control wells with gonadotropins (3). Supplementing culture media with $\mathrm{LH}$ and FSH stimulated endogenous NGF secretion from medium to large follicles in ewes (5). Therefore, the inclusion of gonadotropins in the control medium, but not in the NGF-treated medium, may confound the outcomes of exogenous NGF supplementation since the ovary is capable of endogenous NGF production in response to gonadotropin signaling. It is also worth noting that human chorionic gonadotropin (hCG) was used to treat control samples previously rather than LH (3). While hCG shares the same receptor with $\mathrm{LH}$, hCG also stimulates different intracellular signaling pathways (17), which could alter its downstream effects. Lastly, the current study utilized purified, rather than recombinant NGF to assess species-specific functions of this protein in bovine reproduction. The purified form used in the current study was previously found to be $\sim 59 \%$ pure (7). The major contaminants were found to be a c-type natriuretic peptide (16.41\%) and a serine protease inhibitor (11.26\%).

Interestingly, the c-type natriuretic peptide has been found to inhibit oocyte meiotic resumption in mice (18) and pigs (19), but stimulate oocyte meiotic resumption in cattle (20). Serine protease inhibitors were likely a contaminant from protease inhibitors used during seminal plasma harvest and can have differing effects on fertilization rates when supplemented in vitro (21). While we speculate that the NGF is the primary component causing the results observed in the current study, there is still a need to further elucidate the function of each seminal plasma component through recombinant protein development.

In cattle, ovarian function depends on a complex remodeling of the vascular system between ovulation and CL development that involves the temporal expression of vascular endothelial growth factor A (VEGFA) and fibroblast growth factor 2 (FGF2) (22). Interestingly, there was a downregulation in gene expression of FGF2 and no change in gene expression of VEGFA121 in follicle wall cells treated with NGF. Both VEGFA and FGF2 promote vascular supply growth during follicular to luteal transition in the cow ovary, with resulting changes in their localization patterns $(23,24)$. Follicular FGF2 mRNA and FGF2 protein increased around $4 \mathrm{~h}$ after $\mathrm{GnRH}$ administration in cows, corresponding with the LH surge (25). Immediately following the LH surge, FGF2 stimulates the migration and proliferation of endothelial cells that help to establish luteal blood flow (22). During early CL formation, FGF2 concentrations decrease while the capillary beds are reconstructed to establish blood flow (22). In contrast, VEGFA concentrations remain high throughout ovulation and CL development to support endothelial cell survival (22). Given that the assays were performed after $72 \mathrm{~h}$ in culture, it is possible that the timing of this reconstruction phase was hastened by NGF treatment, which may account for the observed decrease in FGF2 expression. Future studies assessing the temporal expression of these angiogenic enzymes are warranted to clarify exactly how NGF could alter the follicular to luteal transition.

Another factor crucial to ovulation and CL formation is PGE, which can be stimulated from bovine theca cells with NGF treatment $(3,26)$. Previously, NGF treatment stimulated PGE release for up to $8 \mathrm{~h}$ in theca cells extracted 
from bovine preovulatory follicles (3). Prostaglandin $E_{2}$ is synthesized by PGES and acts as a pro-angiogenic molecule in vascular endothelium by recruiting the paracrine-autocrine mechanism characteristic of endothelium cells, resulting in vascular remodeling (27). Prostaglandin $\mathrm{E}_{2}$ also supports luteal progesterone production in cattle (28), potentially through increased CL vascularity (29). Consistently, one study observed higher PGES mRNA and PGES protein levels in the CL of early pregnancy (days 20-30) than in the luteal phase (days 8-12 of the estrous cycle) or after 40 days gestation of artificially inseminated cows (30). To our surprise, NGF treatment did not enhance follicular expression of PGES in the current study. However, HSD17B enzymes have also been found to play a role in the synthesis of arachidonic acid and its downstream eicosanoid metabolites, such as PGE (31). Additionally, HSD17B-knockout female mice failed to initiate pseudopregnancy after being mated by sterile males despite exhibiting normal cycles (32), suggesting a crucial role of this enzyme in CL development. Therefore, NGF may influence ovulation and CL development indirectly through its effects on ovarian HSD17B enzyme activity.

The cultured follicle wall was derived from follicles destined to ovulate within $24 \mathrm{~h}$ based on the synchronization protocol used. Therefore, by $72 \mathrm{~h}$, we expected to see changes consistent with the post-ovulatory follicular to luteal transition. Following ovulation, the LH-receptor-bearing theca cells luteinize and become small luteal cells $(33,34)$. On the other hand, FSH-receptor-bearing granulosa cells luteinize and become large luteal cells, losing their FSH receptors (35). Small luteal cells, in response to $\mathrm{LH}$ binding, produce an early rise in progesterone that is essential for supporting initial embryonic growth (36). Though we found no differences in expression of LHCGR in the current study, it would be worthwhile to evaluate its expression in vivo to determine if there are downstream effects on the presence of small luteal cells in the mature bovine CL. This finding may explain how systemic administration of NGF can improve CL development and function in cattle $(6,7,37)$.

\section{REFERENCES}

1. Dissen GA, Hill DF, Costa ME, Dees W, Les, L.ara HE, et al. A role for TrkA Nerve Growth Factor receptors in mammalian ovulation. Endocrinology. (1996) 137:198-209. doi: 10.1210/endo.137.1.8536613

2. Dissen GA, Romero C, Hirshfield AN, Ojeda SR. Nerve growth factor is required for early follicular development in the mammalian ovary. Endocrinology. (2001) 142:2078-86. doi: 10.1210/endo.142.5.8126

3. Dissen GA, Parrott JA, Skinner MK, Hill DF, Costa ME, Ojeda SR. Direct effects of nerve growth factor on thecal cells from antral ovarian follicles. Endocrinology. (2000) 141:4736-50. doi: 10.1210/endo.141.12.7850

4. Tsafriri A, Lindner HR, Zor U, Lamprecht SA. Physiological role of prostaglandins in the induction of ovulation. Prostaglandins. (1972) 2:110. doi: 10.1016/0090-6980(72)90024-X

5. Mattioli M, Barboni B, Gioia L, Lucidi P. Nerve growth factor production in sheep antral follicles. Domest Anim Endocrinol. (1999) 17:361-71. doi: 10.1016/S0739-7240(99)00056-9

6. Tribulo P, Bogle OA, Mapletoft RJ, Adams GP. Bioactivity of ovulation inducing factor (or nerve growth factor) in bovine seminal plasma and its effects on ovarian function in cattle. Theriogenology. (2015) 83:1394401. doi: 10.1016/j.theriogenology.2014.12.014
In conclusion, the results of the current study demonstrated that purified bovine NGF could act directly on the theca and granulosa cells of the bovine pre-ovulatory follicle to stimulate testosterone production, which may be secondary to theca cell proliferation. Additionally, decreased FGF2 expression in NGFtreated follicle wall cells suggests hastened onset of follicle wall cellular remodeling that occurs during early luteal development.

\section{DATA AVAILABILITY STATEMENT}

The original contributions presented in the study are included in the article/supplementary materials, further inquiries can be directed to the corresponding author.

\section{ETHICS STATEMENT}

The animal study was reviewed and approved by Institutional Animal Care Use Committee.

\section{AUTHOR CONTRIBUTIONS}

JS, FL, and IC conceptualize the study. All authors contributed to the article and approved the submitted version.

\section{FUNDING}

This work was supported by the National Institute of Food and Agriculture at the U.S. Department of Agriculture Hatch Funds (Accession number: 1014712).

\section{ACKNOWLEDGMENTS}

The authors would like to thank the staff at the University of Illinois Veterinary Research Farm and Stephanie Stella and Laís Cunha for assistance with the study.

7. Stewart JL, Mercadante VRG, Dias NW, Canisso IF, Yau P, Imai B, et al. Nerve Growth Factor-Beta, purified from bull seminal plasma, enhances corpus luteum formation and conceptus development in Bos taurus cows. Theriogenology. (2018) 106:30-8. doi: 10.1016/j.theriogenology.2017. 10.007

8. Berland MA, Ulloa-Leal C, Barria M, Wright H, Dissen GA, Silva ME, et al. Seminal plasma induces ovulation in llamas in the absence of a copulatory stimulus: role of nerve growth factor as an ovulation-inducing factor. Endocrinology. (2016) 157:3224-32. doi: 10.1210/en.2016-1310

9. Stewart JL, Canisso IF, Ellerbrock RE, Mercadante VRG, Lima FS. Nerve Growth Factor- $\beta$ production in the bull: gene expression, immunolocalization, seminal plasma constitution, and association with sire conception rates. Anim Reprod Sci. (2018) 197:335-42. doi: 10.1016/j.anireprosci.2018.09.006

10. Knickerbocker JJ, Thatcher WW, Foster DB, Wolfenson D, Bartol FF, Caton D. Uterine prostaglandin and blood flow responses to estradiol-17 $\beta$ in cyclic cattle. Prostaglandins. (1986) 31:757-76. doi: 10.1016/0090-6980(86)90179-6

11. Krzymowski T, Stefańczyk-Krzymowska S, Koziorowski M. Counter current transfer of PGF2 alpha in the mesometrial vessels as a mechanism for prevention of luteal regression in early pregnancy. Acta Physiol. Pol. (1989) 40:23-34. 
12. Schjenken JE, Robertson SA. Seminal fluid signalling in the female reproductive tract: implications for reproductive success and offspring health. In: Bronson R, editor. The Male Role in Pregnancy Loss and Embryo Implantation Failure. Advances in Experimental Medicine and Biology, Vol. 868. Cham: Springer (2015). p. 127-58. doi: 10.1007/978-3-319-18881-2_6

13. Fortune JE. Bovine theca and granulosa cells interact to promote androgen production. Biol Reprod. (1986) 35:292-9. doi: 10.1095/biolreprod35.2.292

14. Komar CM, Berndtson AK, Evans ACO, Fortune JE. Decline in circulating estradiol during the periovulatory period is correlated with decreases in estradiol and androgen, and in messenger RNA for p450 aromatase and p450 17 $\alpha$-hydroxylase, in bovine preovulatory follicles. Biol Reprod. (2001) 64:1797-805. doi: 10.1095/biolreprod64.6.1797

15. Livak KJ, Schmittgen TD. Analysis of relative gene expression data using realtime quantitative PCR and the $2-\Delta \Delta$ CT method. Methods. (2001) 25:4028. doi: $10.1006 /$ meth.2001.1262

16. Berisha B, Pfaffl MW, Schams D. Expression of estrogen and progesterone receptors in the bovine ovary during estrous cycle and pregnancy. Endocrine. (2002) 17:207-14. doi: 10.1385/ENDO:17:3:207

17. Casarini L, Lispi M, Longobardi S, Milosa F, La Marca A, Tagliasacchi D, et al. LH and hCG action on the same receptor results in quantitatively and qualitatively different intracellular signalling. PLoS One. (2012) 7:e46682. doi: 10.1371/journal.pone.0046682

18. Zhang M, Su Y.-Q, Sugiura K, Xia G, Eppig JJ. Granulosa cell ligand NPPC and its receptor NPR2 maintain meiotic arrest in mouse oocytes. Science. (2010) 330:366-9. doi: 10.1126/science.1193573

19. Hiradate Y, Hoshino Y, Tanemura K, Sato E. C-type natriuretic peptide inhibits porcine oocyte meiotic resumption. Zygote. (2014) 22:3727. doi: $10.1017 /$ S0967199412000615

20. De Cesaro MP, Macedo MP, Santos JT, Rosa PR, Ludke CA, Rissi VB, et al. Natriuretic peptides stimulate oocyte meiotic resumption in bovine. Anim Reprod Sci. (2015) 159:52-9. doi: 10.1016/j.anireprosci.2015.05.012

21. Beek J, Maes D, Nauwynck H, Piepers S, Van Soom A. A critical assessment of the effect of serine protease inhibitors on porcine fertilization and quality parameters of porcine spermatozoa in vitro. Reprod Biol. (2015) 15:919. doi: 10.1016/j.repbio.2014.12.002

22. Robinson RS, Woad KJ, Hammond AJ, Laird M, Hunter MG, Mann GE. Angiogenesis and vascular function in the ovary. Reproduction. (2009) 138:869-81. doi: 10.1530/REP-09-0283

23. Tamanini C, De Ambrogi M. Angiogenesis in developing follicle and corpus luteum. Reprod Domest Anim. (2004) 39:20616. doi: 10.1111/j.1439-0531.2004.00505.x

24. Laird M, Woad KJ, Hunter MG, Mann GE, Robinson RS. Fibroblast growth factor 2 induces the precocious development of endothelial cell networks in bovine luteinising follicular cells. Reprod Fertil Dev. (2013) 25:372. doi: 10.1071/RD12182

25. Berisha B, Steffl M, Amselgruber W, Schams D. Changes in fibroblast growth factor 2 and its receptors in bovine follicles before and after GnRH application and after ovulation. Reproduction. (2006) 131:31929. doi: 10.1530/rep.1.00798

26. Nuttinck F, Marquant-Le Guienne B, Clément L, Reinaud P, Charpigny G, Grimard B. Expression of genes involved in prostaglandin E2and progesterone production in bovine cumulus-oocyte complexes during in vitro maturation and fertilization. Reproduction. (2008) 135:593603. doi: 10.1530/REP-07-0453

27. Finetti F, Solito R, Morbidelli L, Giachetti A, Ziche M, Donnini S. Prostaglandin E2 regulates angiogenesis via activation of fibroblast growth factor receptor-1. J Biol Chem. (2008) 283:213946. doi: 10.1074/jbc.M703090200

28. Miyamoto A, Lützow HV, Schams D. Acute actions of prostaglandin F2 $\alpha$, E2, and 12 in microdialyzed bovine corpus luteum in vitro. Biol Reprod. (1993) 49:423-30. doi: 10.1095/biolreprod49.2.423
29. Herzog K, Brockhan-Lüdemann M, Kaske M, Beindorff N, Paul V, Niemann $\mathrm{H}$, et al. Luteal blood flow is a more appropriate indicator for luteal function during the bovine estrous cycle than luteal size. Theriogenology. (2010) 73:691-7. doi: 10.1016/j.theriogenology.2009. 11.016

30. Sakumoto R, Hayashi KG, Takahashi T. Different expression of PGE synthase, PGF receptor, TNF. fas and oxytocin in the bovine corpus luteum of the estrous cycle and pregnancy. Reprod Biol. (2014) 14:11521. doi: 10.1016/j.repbio.2013.12.003

31. Kemiläinen H, Adam M, Mäki-Jouppila J, Damdimopoulou P, Damdimopoulos AE, Kere J, et al. The hydroxysteroid (17 $\beta$ ) dehydrogenase family gene HSD17B12 is involved in the prostaglandin synthesis pathway, the ovarian function, and regulation of fertility. Endocrinology. (2016) 157:3719-30. doi: 10.1210/en.2016-1252

32. Hakkarainen J, Jokela $H$, Pakarinen $P$, Heikel,ä $H$, Kätkänaho L, Vandenput L, et al. Hydroxysteroid (17 $\beta)$-dehydrogenase 1deficient female mice present with normal puberty onset but are severely subfertile due to a defect in luteinization and progesterone production. FASEB J. (2015) 29:3806-16. doi: 10.1096/fj.14-2 69035

33. Mamluk R, Wolfenson D, Meidan R. LH receptor mRNA and cytochrome $\mathrm{P} 450$ side-chain cleavage expression in bovine theca and granulosa cells luteinized by LH or forskolin. Domest Anim Endocrinol. (1998) 15:103-14. doi: 10.1016/S0739-7240(97)0 0085-4

34. Mamluk R, Chen D, Greber Y, Davis JS, Meidan R. Characterization of messenger ribonucleic acid expression for prostaglandin F2 $\alpha$ and luteinizing hormone receptors in various bovine luteal cell types. Biol Reprod. (1998) 58:849-56. doi: 10.1095/biolreprod58.3.849

35. Rajapaksha WR, Robertson L, O'Shaughnessy PJ. Expression of follicle-stimulating hormone-receptor mRNA alternate transcripts in bovine granulosa cells during luteinization in vivo and in vitro. Mol Cell Endocrinol. (1996) 120:25-30. doi: 10.1016/0303-7207(96)0 3816-6

36. Harrison LM, Kenny N, Niswender GD. Progesterone production, LH receptors, and oxytocin secretion by ovine luteal cell types on days 6, 10 and 15 of the oestrus cycle and day 25 of pregnancy. J Reprod Fert. (1987) 79:539-48. doi: 10.1530/jrf.0.07 90539

37. Tanco VM, Van Steelandt MD, Ratto MH, Adams GP. Effect of purified llama ovulation-inducing factor (OIF) on ovarian function in cattle. Theriogenology. (2012) 78:1030-9. doi: 10.1016/j.theriogenology.2012.03.036

Conflict of Interest: The authors declare that the research was conducted in the absence of any commercial or financial relationships that could be construed as a potential conflict of interest.

Publisher's Note: All claims expressed in this article are solely those of the authors and do not necessarily represent those of their affiliated organizations, or those of the publisher, the editors and the reviewers. Any product that may be evaluated in this article, or claim that may be made by its manufacturer, is not guaranteed or endorsed by the publisher.

Copyright (c) 2022 Stewart, Gao, Flaws, Mercadante, Dias, Canisso and Lima. This is an open-access article distributed under the terms of the Creative Commons Attribution License (CC BY). The use, distribution or reproduction in other forums is permitted, provided the original author(s) and the copyright owner(s) are credited and that the original publication in this journal is cited, in accordance with accepted academic practice. No use, distribution or reproduction is permitted which does not comply with these terms. 